Onder redactie van:

Prof. mr. dr. B.M.E.M. Schols

Prof. mr. dr. W. Burgerhart

Prof. mr. dr. F.W.J.M. Schols

Mr. F.M.H. Hoens

Mr. dr. J.W.A. Rheinfeld

Mr. G.A. Tuinstra

Mr. J.Th.M. Diks

Mr. M.J.P. Schipper

Mr. dr. N.V.C.E. Bauduin

Mr. E.C.E. Schnackers

\section{Advotip}

Erfrecht voor de advocaat

\title{
Het agrarisch bedrijf op waarde geschat
}

De waardering van een (in familieverband) overgedragen agrarisch bedrijf heeft, zowel civiel als fiscaal, regelmatig tot felle discussies geleid. Dikwijls is het de legitimaris/nietbedrijfsopvolger die stelt dat er, door de overdracht van de onderneming tegen een waarde die (fors) lager is dan de waarde in het economisch verkeer, sprake is van een gift aan de bedrijfsopvolger/voortzetter. Zeker wanneer de nalatenschap (nagenoeg) uitsluitend bestaat uit (het aandeel van de erflater in) de onderneming, zullen de nietopvolgende kinderen, die het in erfrechtelijke zin dikwijls met een 'legaatje' van een relatief gering geldbedrag, een in-de-legitieme-stelling of soms met helemaal niets moeten doen, zich als legitimarissen erfrechtelijk roeren. De vraag die dan moet worden beantwoord is of de interfamiliaire bedrijfsoverdracht tegen een lagere waarde te kwalificeren is als een ongeoorloofde bevoordeling van de bedrijfsopvolger, hetgeen mogelijk een schending van de legitieme portie oplevert.

Het meest recente voorbeeld van een dergelijke (waarderings)discussie speelde op 31 mei jl. bij de Rechtbank Overijssel (ECLI:NL:RBOVE:2017:2312). Het betrof een in agrarische zin alledaagse casus: een melkveebedrijf, in maatschapsverband uitgeoefend door ouders, zoon en schoondochter, werd, na uittreding van moeder en vervolgens vader, door zoon en schoondochter voortgezet. Conform de bepalingen uit de maatschapsakte vond de overname plaats tegen de 'agrarische waarde': een zodanig bedrag dat de voortgezette exploitatie van het bedrijf nog juist lonend is. Via het testament van vader zijn de overige (niet-opvolgende) kinderen 'in de legitieme gesteld'. In zekere zin zou gezegd kunnen worden dat het aloude 'blijversrecht' anno 2017 in (sommige) agrarische kringen nog steeds actueel is. ${ }^{1}$

De legitimarissen roerden zich in erfrechtelijke zin en betoogden onder meer dat hun broer als bedrijfsopvolging onevenredig en ontoelaatbaar bevoordeeld is. De rechtbank overwoog als volgt:

6.19. Blijkens de (overgelegde) uitspraken van de Hoge Raad van 13 februari 2004 en van 20 maart 2009, en van de rechtbank Noord-Nederland van 23 oktober 2014, geldt in een geval van agrarische bedrijfsopvolging dat, als het uitdrukkelijk de bedoeling van de vennoten is geweest om het bedrijf te laten voortzetten tegen uitbetaling van een zodanig bedrag, dat die voortgezette exploitatie nog juist lonend is, de waardering van de van het bedrijf deel uitmakende zaken niet zo mag zijn, dat die voortzetting van een nog juist lonend bedrijf onmogelijk wordt gemaakt. (Curs. JWAR)

\footnotetext{
${ }^{1}$ Zie M.A. Cohen, Het blijversrecht : Een notarieel juridische studie over het Oost-Nederlandse recht betreffende de vererving en de overgang bij leven van landbouwbedrijven (diss. 1958), Deventer: Kluwer 1970.
} 
De vorderingen van de (ontevreden) legitimarissen worden getoetst aan de hand van het in het civiele 'standaardarrest' van 13 februari 2004 (ECLI:NL:HR:2004:AN8172) en de fiscale pendant daarvan van 20 maart 2009 (ECLI:NL:HR:2009:BF1029) ontwikkelde toetsingskader.

Dat brengt onder meer met zich dat de overnameprijs van een onderneming, voor zover een duidelijke bepaling dienaangaande in de vennootschapsakte ontbreekt, in civielrechtelijke zin (2004) moet worden bepaald aan de hand van drie factoren:

1. de maatstaven van redelijkheid en billijkheid, die in het algemeen in de weg staan aan een waardering die voortzetting van een (nog juist lonend) bedrijf onmogelijk maakt;

2. de bedoeling van de vennoten dat een (of meer) van hen het bedrijf na de ontbinding van de vennootschap zou(den) kunnen voortzetten tegen voldoening van een vergoeding waarbij exploitatie van het bedrijf nog juist lonend is;

3. de aard van de rechtsverhouding tussen de deelgenoten, in dit geval gekenmerkt door het feit dat het gaat om de samenwerking in het kader van een in familieverband uitgeoefend melkveebedrijf.

Voorts moet, voor de beoordeling of in fiscale zin (2009) sprake is van een gift, naar de volgende elementen gekeken worden:

- is er sprake van een aan de overdracht voorafgaand samenwerkingsverband;

- waarbij vooraf reële afspraken zijn gemaakt op basis van het uitgangspunt dat het kind de onderneming te zijner tijd rendabel moet kunnen voortzetten en waarbij een waarderingsmaatstaf wordt afgesproken die noodzakelijk is om voortgezette bedrijfsuitoefening mogelijk te maken;

- is sprake van reële uitvoering van die afspraken; en

- is een meerwaardeclausule bedongen.

Aan de hand van deze piketpalen wordt de te berechten casus beoordeeld:

6.20. Dat betekent dat, zoals ook in dit geval is gebeurd, de beoogde bedrijfsopvolger bedrijfsactiva in handen kan krijgen tegen veel lagere prijzen dan hun waarde in het vrije economisch verkeer. Van schenking is dan toch geen sprake. Immers, als de beoogde bedrijfsopvolger de bedrijfsactiva tegen marktprijzen zou moeten verwerven zou hij het bedrijf niet rendabel kunnen voortzetten en zou de door de vennoten beoogde bedrijfsopvolging niet mogelijk zijn. Een waardering van de zaken die voortzetting van een nog juist lonend bedrijf mogelijk maakt strekt niet tot bevoordeling. (Curs. JWAR)

De redelijkheid en billijkheid, gecombineerd met de bedoeling om de bedrijfsopvolger de kans te geven om het bedrijf rendabel te kunnen laten exploiteren, ontnemen aan de bedrijfsopvolging de bevoordelingsbedoeling en daardoor het schenkingskarakter.

Daarmee zijn we er echter nog niet helemaal:

6.21. Een dergelijk geval is ook in de onderhavige zaak aan de orde. In het vonnis van de rechtbank Noord-Nederland wordt daarnaast nog de eisen van (1) advisering en begeleiding door agrarische deskundigen en (2) een meerwaardeclausule. Ook in de onderhavige zaak is aan die twee voorwaarden voldaan. (Curs. JWAR)

Rechtbank Noord-Nederland heeft op 22 oktober 2014 (ECLI:NL:RBNNE:2014:5188) een tweetal extra eisen gesteld, die bij de beoordeling of sprake is van (on)toelaatbare bevoordeling moeten worden meegenomen. Advisering en begeleiding door agrarisch deskundigen (lees: de agro-advocaat) en een meerwaardeclausule (een element dat ook in het fiscale arrest uit 2009 werd genoemd) vormen, naast de hiervoor vermelde 
gezichtspunten, het toetsingskader voor de toelaatbaarheid van een bedrijfsovername tegen een lagere (agrarische) waarde.

Ook aan deze aanvullende voorwaarden is in casu voldaan. Daarmee is dit een bedrijfsoverdracht 'uit het (agrarische) boekje'.

De conclusie in rechtsoverweging 6.22 zal daarom weinig verbazing wekken:

6.22. Er was daarom geen sprake van ongeoorloofde bevoordeling van $[X]$ als bedrijfsopvolger ten opzichte van zijn zusters. Van schending van de legitieme porties van $[B],[C],[D]$ en $[E]$ is dus geen sprake. (Curs. JWAR)

Het moge duidelijk zijn: de onmogelijkheid om een tegen de waarde in het economisch verkeer overgenomen agrarisch bedrijf rendabel te kunnen voortzetten legitimeert, mits aan diverse nadere eisen wordt voldaan, een overdracht van dit bedrijf tegen een lagere waarde en houdt de (ontevreden) legitimaris(sen) succesvol op afstand. 'Ruim baan voor de (agrarische) bedrijfsopvolger' luidt dan het devies.

Tot de volgende keer!

Mr. dr. J.W.A. Rheinfeld

Radboud Universiteit Nijmegen

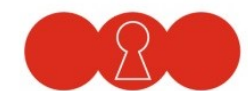

ScholsBurgerhartSchols

www.scholsburgerhartschols.nl

\section{Boomjuridisch}

Postbus 85576

2508 CG Den Haag

$\mathrm{T}(070) 3307033$

E info@boomjuridisch.nl

l www.boomjuridisch.nl 